\title{
Characteristics of airborne bacteria and fungi in some Polish wastewater treatment plants
}

\author{
M. Kowalski ${ }^{1}$ (D) J. Wolany ${ }^{1} \cdot$ J. S. Pastuszka $^{1} \cdot$ G. Płaza $^{2} \cdot$ A. Wlazło $^{3} \cdot$ \\ K. Ulfig ${ }^{4}$ A. Malina ${ }^{1}$
}

Received: 27 September 2016/Revised: 25 January 2017/ Accepted: 2 March 2017/Published online: 13 March 2017

(C) The Author(s) 2017. This article is published with open access at Springerlink.com

\begin{abstract}
The aim of this study was to characterize both the viable airborne bacteria and fungi collected in different types of wastewater treatment plants in Poland. Bacterial and fungal aerosols in five different wastewater treatment plants in Poland were studied, including the pioneering antibiotic resistance testing of airborne bacteria. Concentration level was measured using the six-stage Andersen impactor. After incubation, bioaerosol particles captured on nutrient media on Petri dishes were quantitatively evaluated and qualitatively identified. It was found that the concentration levels of both airborne bacteria and fungi ranged from $10^{2}$ to $10^{3}$ colony-forming units $/ \mathrm{m}^{3}$, in all stages of the wastewater treatment plants. The patterns of size distributions of airborne bacteria and fungi were very similar, showing dominant peaks typically in the size range between 3.3 and $4.7 \mu \mathrm{m}$. The majority fraction of small bacterial and fungal particles (less than $4.7 \mu \mathrm{m}$ ) in the studied areas indicates that the bioaerosol is relatively fresh, and mostly of local origin. The Gram-positive cocci and nonsporing Gram-positive rods were the dominating
\end{abstract}

Editorial responsibility: M. Abbaspour.

M. Kowalski

michal.kowalski@polsl.pl

1 Faculty of Energy and Environmental Engineering, Department of Air Protection, Silesian University of Technology, 22B Konarskiego St., 44-100 Gliwice, Poland

2 Institute of Ecology of Industrial Areas, 6 Kossutha St., 40-832 Katowice, Poland

3 Institute of Occupational Medicine and Environmental Health, 13 Kościelna St., 41-200 Sosnowiec, Poland

4 Department of Post-Industrial Sites and Waste Management, Central Mining Institute, 1 Plac Gwarków, 40-166 Katowice, Poland forms in the studied wastewater treatment plants environment. The existing differences in the concentration levels between sampling sites enabled identification of the main bioaerosol sources. The highest concentration of bacterial aerosol appeared in sections, where activated sludge postprocessing and mechanical purifying are conducted. The most frequently occurring species in the sampled bacterial aerosol were Gram-positive cocci and nonsporing Grampositive rods. Multi-antibiotic resistance testing showed that among the isolated airborne bacteria, the most antibiotic-resistant features were present among Bacillus species (especially Bacillus mycoides).

Keywords Wastewater plants - Bioaerosols - Airborne bacteria $\cdot$ Airborne fungi $\cdot$ Antibiotic resistance

\section{Introduction}

Although microorganisms suspended in the air are described as "airborne microorganisms" or "bioaerosols" (Di Giulio et al. 2010), bioaerosols are, in fact, a loosely defined group of airborne particles of viable and dead biological origin, i.e., viruses, bacteria, fungal spores, pollen and various antigens, their fragments and compounds produced by microorganisms. Bioaerosols can become a serious risk to health of the population, particularly with regard to people occupationally exposed to them (e.g., employees of the wastewater treatment plant or landfills, farmers, breeders and people employed in food industry processing). Also people living in the vicinity of those plants, where bioaerosol contaminants are emitted, are particularly vulnerable to this kind of pollution. Especially, airborne bacteria and fungi can cause not only infection diseases, but allergic and toxic effects too. The 
epidemiological studies showed that the occurrence of hypersensitivity diseases (for example, humidifier fever, asthma) is often associated with exposure to the high concentration of airborne microbes (ACGIH 1989). Analysis of the literature data made by Thorn and Kerekes (2001) indicates that such symptoms like general malaise, weakness, acute rhinitis and fever, accompanied by gastrointestinal problems-appearing among workers at wastewater treatment plants may be caused by the exposure to endotoxin contained in Gram-negative bacteria.

In practice, concentration of viable bacteria and fungi suspended in the air can be estimated nondirectly by measuring the number of airborne units of microorganisms able to form colonies on the agar-per cubic meter, colony-forming units per cubic meter $\left(\mathrm{CFU} / \mathrm{m}^{3}\right)$.

Wastewater treatment plants (WWTPs) are one of the biggest industries, where bioaerosols can be emitted. Process conducted in a biological wastewater treatment plant requires contribution of variety of microorganisms (also pathogens), such as bacteria, fungi and other organisms, like rotifers, nematodes. Due to the mechanism of treating the sewage (involving mixing and aeration) which consists of water, microorganisms and contaminants, formation and releasing in form of bioaerosol is very common in such plants. Literature data indicate that the amounts of emitted bacteria and fungi vary, depending on the stage of the process and the technique used in the process of aeration and mixing the sewage in bioreactors. Sánchez-Monedero et al. (2008) suggest that mechanical agitation of wastewater using horizontal rotors and surface turbines causes higher concentration of bioaerosols $\left(450-4580 \mathrm{CFU} / \mathrm{m}^{3}\right)$ than the diffuser aerators $\left(22-57 \mathrm{CFU} / \mathrm{m}^{3}\right)$. Authors also concluded that the highest amounts of bioaerosol particles are emitted during pretreatment, biological treatment and sludge thickening. Also the type of wastewater treatment plant determines the amount of bioaerosol emission. Results obtained by Bauer et al. (2002) indicated that more bacteria and fungi are emitted by the aeration tank of activated sludge plant than from fixed-film bioreactor. Experiment concerning investigation of bioaerosols emitted in WWTP in Beijing, China, revealed that there are differences in concentration levels between particular stages of treatment plant (near sludge thickening basin detected highest level of culturable bacterial and fungal aerosols). Indicated also the occurrence of the potentially antibiotic-resistant bacterial strains (Li et al. 2016). There is also a seasonal variability in bioaerosol concentrations collected in different seasons, similarly to the environmental conditions. Bacterial aerosol concentrations were significantly higher during summer; furthermore, mannitolpositive staphylococci were only present in WWTP during this season (Szylak-Szydlowski et al. 2016).
Because adverse health effects caused by the inhalation of bioaerosols depend not only on the absorbed dose but also on the contribution of pathogens in the total amount of airborne microorganisms, it is important to identify their genera and species. Among the microorganism present in the air at the areas of wastewater treatment plants and in their vicinity were found both saprophytes and pathogens of the genera Bacillus, Clostridium, Enterobacter, Escherichia, Klebsiella, Mycobacterium, Pseudomonas, Serratia, Staphylococcus, Salmonella, and such fungi as Alternaria, Cladosporium, Penicillium, Aspergillus (Wlazło et al. 2002; Fracchia et al. 2006; Korzeniewska et al. 2009).

Recently, it has also become essential to evaluate the antibiotic resistance of the airborne bacteria. There is no such information in previous studies concerning the bioaerosol emissions from wastewater treatment plants. On the other hand, it is known that urban wastewater treatment plants are among the main sources of antibiotics release into various compartments of the environment worldwide (Michael et al. 2013), and the existence of antibiotic-resistant bacteria in the water environment in such plants was documented (Novo et al. 2013; Bouki et al. 2013).

The main objective of this study was to estimate the concentrations of viable airborne bacteria and fungi in different stages of selected wastewater treatment plants in Poland and describe their physical and biological characteristics. Sampling was carried out in November 15 in WWTPs located in Poland. Testing of the airborne bacteria, collected in these plants, for antibiotic resistance was also performed.

\section{Materials and methods}

\section{Characteristics of the WWTPs}

The studies were conducted at five different wastewater treatment plants located in Poland. Two of them were treating municipal wastewater (identified as "Zabrze" and "Karkoszka"), other two were located in the area of the coking coal plant ("Przyjaźń" and "Radlin"), and one WWTP was treating sewage from the food producing industry ("Langer"). Municipal and coking wastewater treatment plants are located in Upper Silesia, southern Poland, while WWTP treating sewage form food industry is placed in Wielkopolska region, central-west part of Poland. All plants use the activated sludge to treat the wastewater. Municipal WWTPs could be characterized by specifying the size of the plant by daily flow of sewage. General characteristics of the plants are presented in Table 1. 
Table 1 Characteristics of the studied wastewater treatment plants (WWTPs)

\begin{tabular}{llll}
\hline Mark & Name of the WWTP & Aeration system in biological reactor & Size of the WWTP (flow rate) \\
\hline $\mathrm{Z}$ & Zabrze & AD-fine bubbles & $33,400 \mathrm{~m}^{3} / \mathrm{d}$ \\
$\mathrm{K}$ & Karkoszka & AD-membrane diffusers & $15,000 \mathrm{~m}^{3} / \mathrm{d}$ \\
$\mathrm{P}$ & Przyjaźń & AD—fine bubbles & $-{ }^{\mathrm{a}}$ \\
$\mathrm{R}$ & Radlin & AD-liquid oxygen & $-{ }^{\mathrm{a}}$ \\
$\mathrm{L}$ & Langer & AD—membrane bubbles & $300-420 \mathrm{~m}^{3} / \mathrm{d}$ \\
\hline
\end{tabular}

$A D$ air diffusion

${ }^{a}$ For WWTP treating coking wastewater, daily inflow is not given (depends on the production rate)
During the experiment, concentrations of emitted bioaerosols in different stages of treatment on each WWTP were measured, concerning: pretreatment, biological treatment and activated sludge post-processing. Coking wastewater treatment plants (P and R) did not have in their process lines of mechanical treatment, while others (municipal Z, K and food processing L) had. As background, we assumed the concentrations outside the WWTPs, without the influence of emitted bioaerosols, during the same day and meteorological conditions.

\section{Sampling}

Since the purpose of this research was to assess the exposure to bacterial and fungal aerosol in the five studied plants in almost the same meteorological conditions, all samples were collected during one month-in November, during the days with temperature not exceeding $15^{\circ} \mathrm{C}$, wind speed lower than $2.5 \mathrm{~m} / \mathrm{s}$ and humidity in range 60-90\%. More detailed data concerning meteorological conditions during sampling are presented in Table 2.

Measurements of the bioaerosol concentrations were taken using 6-stage Andersen impactor (with cutoff diameters 7.0, 4.7, 3.3, 2.1, 1.1 and $0.65 \mu \mathrm{m}$ ), one of the most popular and frequently treated as a reference device in biological aerosol studies. This sampler works by air aspiration through the multiple hole stages below which is placed a Petri dish containing appropriate agar media. Air drawn through a jet is deflected $90^{\circ}$ by the agar surface below the jet.
Through the inertial impaction, microorganisms are transferred from the air onto the agar surface. Each stage has 400 round holes with decreasing (from stage to stage) diameters.

During the measurements, the air flow was $28.3 \mathrm{dm}^{3} /$ min and the sampling time, calculated following Nevalainen et al. (1992), was $8 \mathrm{~min}$. Before and after sampling, the flow rate was measured using a rotameter. Microorganisms were collected on nutrient media (specific to either fungi or bacteria) in Petri dished located on all impactor stages. Trypticase soy agar (TSA) was used for bacteria, with cycloheximide added to inhibit fungal growth. Malt extract agar (MEA 2\%) was applied for fungi, with chloramphenicol added to inhibit bacterial growth.

Medium was previously prepared and sterilized in autoclave, before pouring it in Petri dishes. Before and between sampling, the impactor was sterilized with methyl alcohol and periodically cleaned using ultrasonic cleaner.

Samples were collected at the same height, approximately $1.5 \mathrm{~m}$ from the platform level. Average height of the platform was $0.8 \mathrm{~m}$ above wastewater level. The example of the sampling process is shown in Fig. 1.

\section{Laboratory analysis}

Bioaerosol particles sampled on Petri dishes inside the Andersen impactor were incubated for 3-4 days in room temperature in incubators (bacteria $20^{\circ} \mathrm{C}$, fungi $22^{\circ} \mathrm{C}$ ). Concentrations were counted as the number of grown colonies and expressed as colony-forming units per cubic meter $\left(\mathrm{CFU} / \mathrm{m}^{3}\right)$ using positive hole corrections.

Table 2 Meteorological conditions at the wastewater treatment plants during sampling

\begin{tabular}{llllll}
\hline WWTP & Date of sampling & Air temperature $\left({ }^{\circ} \mathrm{C}\right)$ & Humidity $(\%)$ & Wind speed $(\mathrm{m} / \mathrm{s})$ & Comments \\
\hline Zabrze & November 12 & 10.5 & 79 & 2 & Gusts of wind \\
Karkoszka & November 20 & 8.2 & 74 & 1.5 & - \\
Przyjazn & November 18 & 11.1 & 81.2 & 0.5 & Gusts of wind, light drizzle \\
Radlin & November 16 & 13.9 & 89 & 1 & - \\
Langer & November 9 & 11.3 & 82.1 & 0 & Calm \\
\hline
\end{tabular}




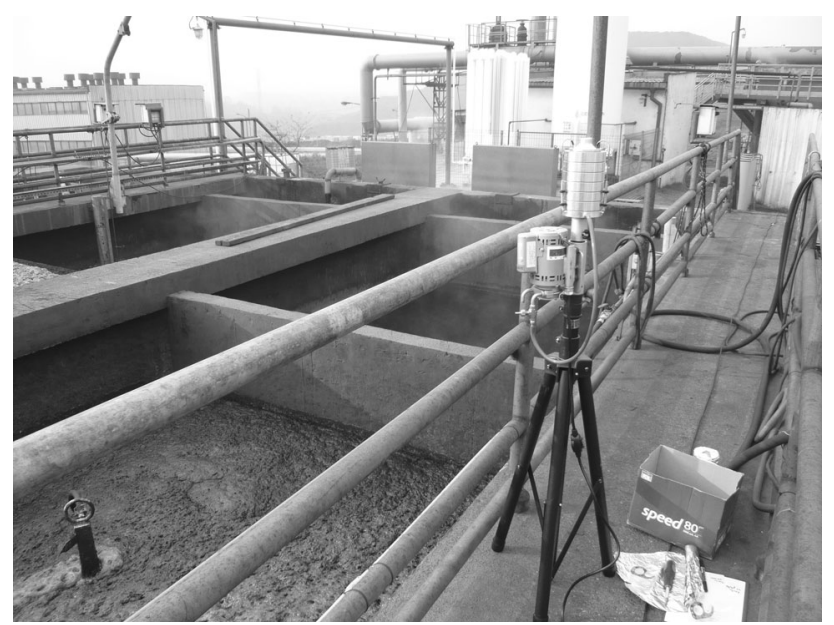

Fig. 1 Sampling of bioaerosol particles in the wastewater Radlin (R)

Microscopic analysis of collected bacteria was based on Gram strain preparations and on cells size, shape and the appearance of spores. The possibility to cultivate the strains isolated on agar medium with blood addition (trypticase soy agar with $5 \%$ of the sheep blood) was also estimated. Bacteria were characterized in terms of their metabolic characteristic, using biochemical tests Analytical Profile Index (API), supported by APIweb (bioMérieux, Marcyl'Etoile, France) application. In presented research, the following API systems were used: API 20E, API 20NE, API 50CH, API CORYNE, API STAPH and API STREP.

Chosen Petri dishes from sampling stages, corresponding to the specific sampling sites as biological reactors and aeration tanks, with cultivated fungi were also analyzed to qualitatively identify the species. Strains were isolated and microbiologically purified. Species identification based on macro- and micro-morphological features and chosen biochemical characteristics, according to the literature. Penicillium strains identification was conducted using diagnostic culture mediums: malt extract agar (MEA), Czapek yeast autolysate (CYA), yeast extract sucrose (YES) and creatine sucrose agar (CREA). Incubation of Penicillium strains was conducted in 25 and $37^{\circ} \mathrm{C}$. The strain's ability to produce indole alkaloids, using Ehrlich reaction (DMAB test) was also determined.

\section{Multi-antibiotic resistance test}

Cultivated bacteria, previously identified using API technique, were also tested for the multi-antibiotic resistance (MAR). In this experiment, isolated strains from the cultivated bacteria were taken. Onto solid medium MuellerHinton (Oxoid, USA), $100 \mu \mathrm{l}$ suspension of bacteria selected strains was poured, with optical density $\mathrm{OD}_{600}=0.3-0.4$ (enumeration spread plate method). Then, onto growth medium with bacterial suspension placed antimicrobial
Table 3 Anitbiotics and their doses used in multi-antibiotic resistance test

\begin{tabular}{llcl}
\hline Antibiotic & Symbol & Dose $(\mu \mathrm{g})$ & Code \\
\hline Amoxycillin & AML & 25 & CT0061B \\
Ampicillin & AMP & 25 & CT0004B \\
Ceftazidime & CAZ & 30 & CT0412B \\
Cefalotin & KF & 30 & CT0010B \\
Cefuroxime sodium & CXM & 30 & CT0127B \\
Nalidixic acid & NA & 30 & CT0031B \\
Amikacin & AK & 30 & CT0107B \\
Doxycycline & DO & 30 & CT0018B \\
Erythromycin & E & 30 & CT0021B \\
Gentamicin & CN & 30 & CT0072B \\
Kanamycin & K & 30 & CT0026B \\
Neomycin & N & 30 & CT0033B \\
Streptomycin & S & 25 & CT0048B \\
Tobramycin & TOB & 10 & CT0056B \\
Tetracycline & TE & 30 & CT0054B \\
Trimethoprim & W & 5 & CT0076B \\
Rifampicin & RD & 30 & CT0207B \\
Chloramphenicol & C & 30 & CT0013B \\
Nitrofurantoin & F & 200 & CT0035B \\
Novobiocin & NV & 30 & CT0038B \\
\hline & & &
\end{tabular}

susceptibility testing disks (Oxoid, USA). Tested 20 antibiotics, chosen from the available and in concentrations corresponded to those mostly often appearing in the literature concerning antibiotic resistance. Among them, were tested: amoxycillin, ampicillin, ceftazidime, cefalotin, cefuroxime sodium, nalidixic acid, amikacin, doxycycline, erythromycin, gentamicin, kanamycin, neomycin, streptomycin, tobramycin, tetracycline, trimethoprim, rifampicin, chloramphenicol, nitrofurantoin and novobiocin. Performed 2-3 repetitions of each tested antibiotics. Specific doses of the antibiotics are presented in Table 3 .

Chosen antibiotics represent 7 different groups in terms of their chemical structure: penicillins, cephalosporins, quinolones, aminoglycosides, tetracyclines, sulfonamides, rifampicins and other. Petri dishes with bacteria were incubated in $30{ }^{\circ} \mathrm{C}$ for $24 \mathrm{~h}$. After incubation, the areas of growth inhibition were measured, and three-stage scale was applied to assess the bacteria resistance to antibiotics: diameter of growth inhibition $<15 \mathrm{~mm}$-bacterial resistance to antibiotic $(R)$; diameter of growth inhibition between 16 and $25 \mathrm{~mm}$-bacteria intermediate resistance to antibiotic (I); diameter of growth inhibition $>25 \mathrm{~mm}$ - bacteria sensitive to antibiotic $(S)$.

\section{Results and discussion}

Obtained concentration levels of bacterial and fungal aerosols are presented in Table 4. 
Table 4 Concentration of airborne bacteria and fungi in different stages of the wastewater treated process in the studied plants

\begin{tabular}{llllll}
\hline & Przyjaźń & Radlin & Zabrze & Karkoszka & Langer \\
\hline Bacterial aerosol $\left(\mathrm{CFU} / \mathrm{m}^{3}\right)$ & & & & \\
Background & $5.3 \times 10^{1}$ & $1.1 \times 10^{3}$ & $2.2 \times 10^{2}$ & $1.2 \times 10^{2}$ & - \\
Mechanical treatment & - & - & $5.5 \times 10^{2}$ & $1.1 \times 10^{3}$ & $6.9 \times 10^{3}$ \\
Biological treatment & $2.1 \times 10^{2}$ & $6.4 \times 10^{2}$ & $4.3 \times 10^{2}$ & $2.4 \times 10^{2}$ & $6.3 \times 10^{2}$ \\
Clarifiers & $1.1 \times 10^{2}$ & $8.6 \times 10^{2}$ & $7.4 \times 10^{2}$ & $8.0 \times 10^{1}$ & $5.7 \times 10^{2}$ \\
Sludge post-processing & $1.3 \times 10^{3}$ & $1.8 \times 10^{3}$ & $1.2 \times 10^{3}$ & $1.9 \times 10^{3}$ & $2.8 \times 10^{3}$ \\
Fungal aerosol (CFU/m $\left.{ }^{3}\right)$ & & & & & \\
Background & $1.2 \times 10^{3}$ & $1.1 \times 10^{3}$ & $7.1 \times 10^{2}$ & $6.3 \times 10^{2}$ & $9.0 \times 10^{2}$ \\
Mechanical treatment & - & - & $7.4 \times 10^{2}$ & $6.1 \times 10^{2}$ & $3.9 \times 10^{3}$ \\
Biological treatment & $1.4 \times 10^{3}$ & $5.1 \times 10^{2}$ & $9.7 \times 10^{2}$ & $7.5 \times 10^{2}$ & $5.7 \times 10^{2}$ \\
Clarifiers & $1.7 \times 10^{3}$ & $1.0 \times 10^{3}$ & $7.4 \times 10^{2}$ & $5.5 \times 10^{2}$ & $6.5 \times 10^{2}$ \\
Sludge post-processing & $9.4 \times 10^{2}$ & $5.8 \times 10^{2}$ & $1.3 \times 10^{3}$ & $5.1 \times 10^{2}$ & $5.6 \times 10^{2}$ \\
\hline
\end{tabular}

It can be seen that the levels of airborne fungi were very similar to those registered at the background location $\left(10^{2}-\right.$ $10^{3} \mathrm{CFU} / \mathrm{m}^{3}$ ), unaffected by the activities taking place in the wastewater treatment plants. Furthermore, similar, quite high concentrations were obtained for backgrounds (outside these plants).

In the most of the studied plants, also the concentration of airborne bacteria was comparable with the background bioaerosol. The same result was previously reported by Sánchez-Monedero et al. (2008). Only in the all stages of the WWTP "Przyjaźń", the concentration levels of bacterial aerosol were significantly elevated compared to the background, but it should be remarked that the background level was very low there.

As presented, the highest concentration of bacterial aerosol was found in these parts of wastewater treatment plant, where activated sludge post-processing and (in some plants) process of mechanical purifying were conducted $\left(1.2 \times 10^{3}-2.8 \times 10^{3} \mathrm{CFU} / \mathrm{m}^{3}\right.$ and $5.5 \times 10^{2}-$ $6.9 \times 10^{3} \mathrm{CFU} / \mathrm{m}^{3}$, respectively). This may be referred to fact that the process of mechanical treating and post-processing of activated sludge on WWTPs, where sampling was carried out, is conducted indoor, in the buildings, e.g., of screened solids or hydraulic presses of the sludge. Concentrations of bacterial aerosol emitted in stage of biological reactors and clarifiers were in the level of $10^{2}$ $\mathrm{CFU} / \mathrm{m}^{3}$. Similar results were reported by others. Results obtained in case of samples from different stages of municipal WWTP in Spain shown that the highest amount of heterotrophic bacteria $\left(5.6 \times 10^{3} \mathrm{CFU} / \mathrm{m}^{3}\right)$ were noted in pretreatment section, while in other parts were significantly lower $\left(2.2 \times 10^{3} \mathrm{CFU} / \mathrm{m}^{3}\right.$ in primary clarifiers and $5 \times 10^{2} \mathrm{CFU} / \mathrm{m}^{3}$ in aeration basins) (Pascual et al. 2003). For example, Karra and Katsivela (2007) found that in Greece the highest concentrations of airborne microorganisms were observed at the aerated grit removal of wastewater at the pretreatment stage (mesophilic heterotrophic bacteria: $933 \pm 636 \mathrm{CFU} / \mathrm{m}^{3}$; fungi: $380 \pm 200 \mathrm{CFU} / \mathrm{m}^{3}$ ) than in indoor control (bacteria: $515 \pm 295 \mathrm{CFU} / \mathrm{m}^{3}$; fungi: $160 \pm 50 \mathrm{CFU} / \mathrm{m}^{3}$ ). Wlazło et al. (2002) studied distribution of the exposure to airborne bacteria inside the small wastewater treatment plant in Myszków, Poland, obtaining the concentration level of total bacteria between $10^{2}$ and $10^{3} \mathrm{CFU} / \mathrm{m}^{3}$ and indicated that the highest level was near the aeration basin. Bauer et al. (2002) also found in wastewater treatment plants in Austria (where the averaged concentrations of mesophilic bacteria and fungi were $1.7 \times 10^{4}$ and $1.7 \times 10^{3} \mathrm{CFU} / \mathrm{m}^{3}$, respectively) the highest exposure to bacterial and fungal aerosols during aeration. Korzeniewska et al. (2009) studied emission of airborne microorganisms from WWTP with bioreactor "BIO-PAK" found that the highest concentrations of bacteria $\left(10^{1}-10^{3} \mathrm{CFU} / \mathrm{m}^{3}\right)$ and fungi $\left(10^{4} \mathrm{CFU} /\right.$ $\mathrm{m}^{3}$ ) were determined in air sampled inside the bioreactor, in its vicinity, and near the great chamber. It is interesting to note that in the studies concerning exposure to bioaerosol from sewage systems in Austria, the highest concentrations of mesophilic bacteria were found in the encased grit chamber. During high-pressure cleaning, total bacterial concentrations reached up to $4.0 \times 10^{4} \mathrm{CFU} / \mathrm{m}^{3}$, including coliforms (up to $3.0 \times 10^{3} \mathrm{CFU} / \mathrm{m}^{3}$ ) (Haas et al. 2009).

Generally, the distribution of the airborne bacterial levels in the area of the studied waste water treatment plants agrees well with the existing knowledge (SánchezMonedero et al. 2008; Fracchia et al. 2006). In particular, we confirmed that splashing and bubble bursting that occur as a result of forced aeration in activated sludge processes release large amount of bacteria into the air.

Analysis of the number and aerodynamic diameter of viable microorganisms collected on different stages of the impactor in the all studied wastewater treatment plants is presented in Figs. 2 and 3. It can be seen that the size 
(a) mechanical treatment

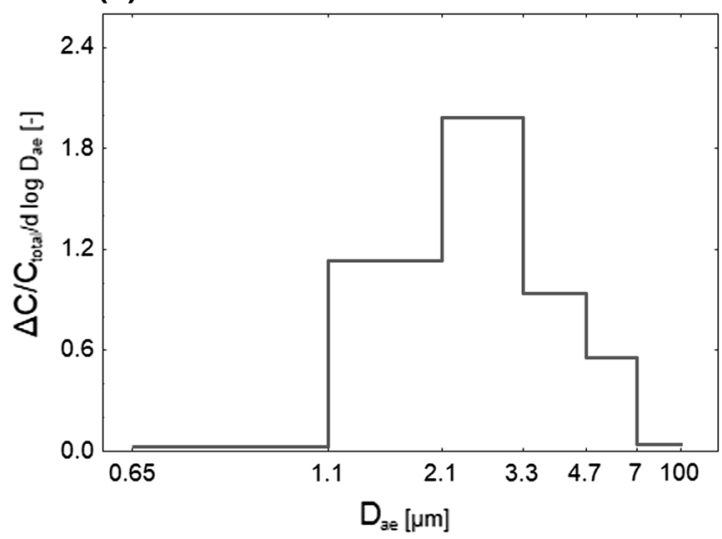

(c) clarifiers

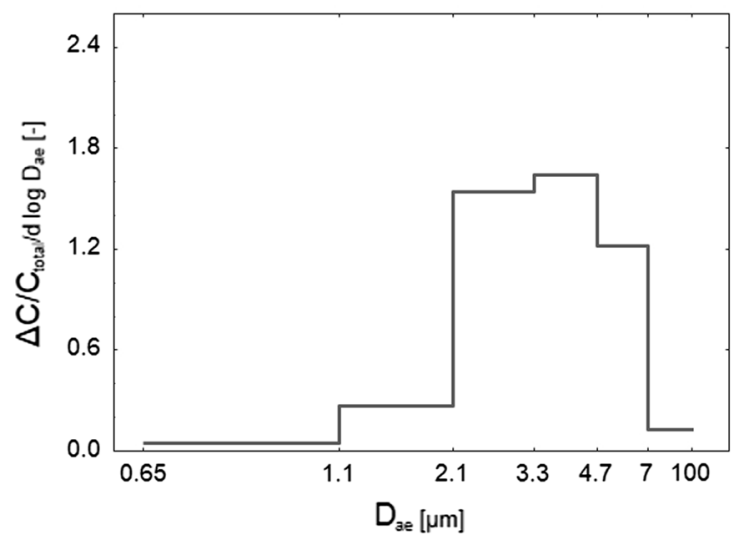

(b) aeration tanks

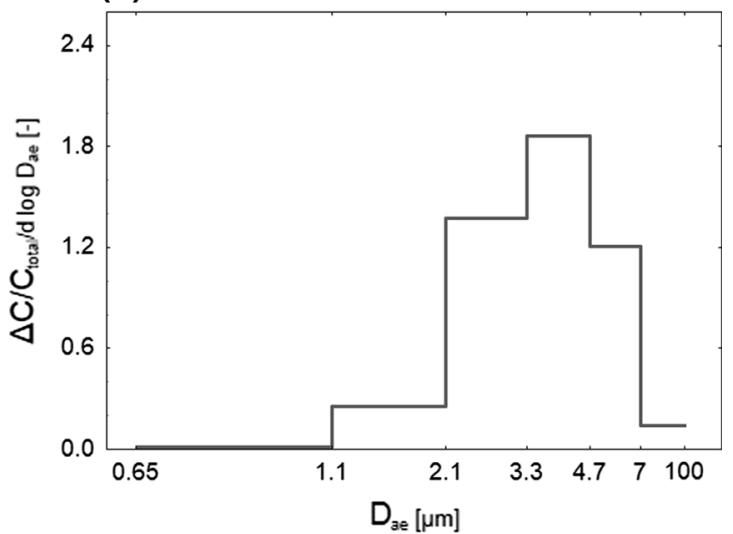

(d) sludge post-processing

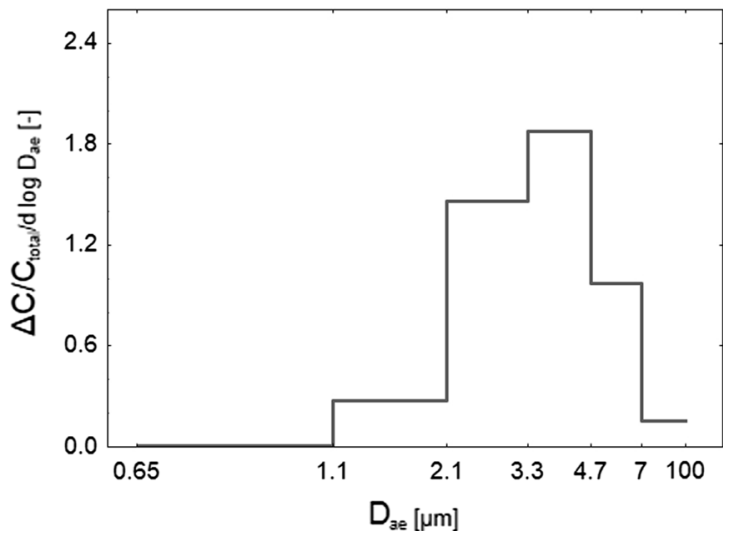

Fig. 2 Size distributions of airborne fungi collected in the studied wastewater treatment plants

distributions of airborne bacteria in the section of the clarifiers and the sludge post-processing have the peak in the size range between 2.1 and $3.3 \mu \mathrm{m}$ while in the section of mechanical treatment, as well as in the aeration tanks the peak appears in the size range $3.3-4.7 \mu \mathrm{m}$, i.e., is shifted into larger particles. These results agree well with the other reports, especially with the data published by Laitinen et al. (1994) who found that most of the bacteria-carrying particles in the air of a WWTP had an aerodynamic diameter below $4.7 \mu \mathrm{m}$.

It is interesting to note that the patterns of the size distributions of airborne fungi are generally very similar to bacterial size distributions but have the peaks, typically, in the size range between $2.1-3.3$ and $3.3-4.7 \mu \mathrm{m}$. This is typical size distribution pattern for airborne fungi, and similar results have been obtained in highly moldy homes in Poland (Pastuszka et al. 2000, 2005). As it can be seen the contribution of fine fungal particles (less than $2.1 \mu \mathrm{m}$ ) is significant in the section of the mechanical treatment and aeration tanks.
On the other hand, it should be noted that bioaerosol particles less than $4.7 \mu \mathrm{m}$ should be classified as the relatively small, respirable particles. The dominating mode of small airborne bacteria and fungi in the sampling sites which may indicate that the studied bioaerosol is relatively fresh, and mostly local origin.

Percentage composition of bacterial aerosols sampled in the studied WWTPs is shown in Fig. 4. It can be seen that among the isolated bacterial species the following two groups occurred more frequently than others: Gram-positive cocci and nonsporing Gram-positive rods. Main sources of emission of Gram-positive cocci are human organisms, but also the environment (soil, water), especially in case of $\mathrm{Mi}$ crococcus/Kocuria species. As nonsporing Gram-positive rods can be frequently found in soil, plants, water, sewage, etc., they are also typical bacteria in the wastewater treatment plant environment. Share of the other bacteria groups, involving endospore-forming Gram-positive bacilli, mesophilic actinomycetes, and Gram-negative rods, was $1 / 4$ of the total bacterial aerosols in the studied plants. 
(a) mechanical treatment

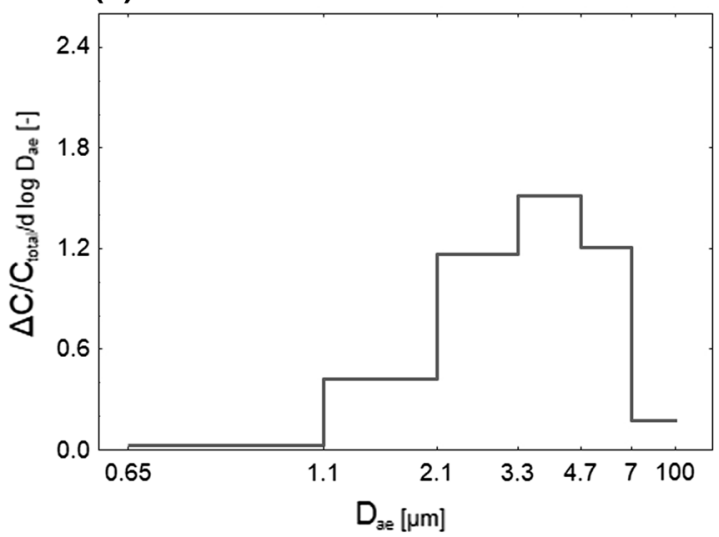

(c) clarifiers

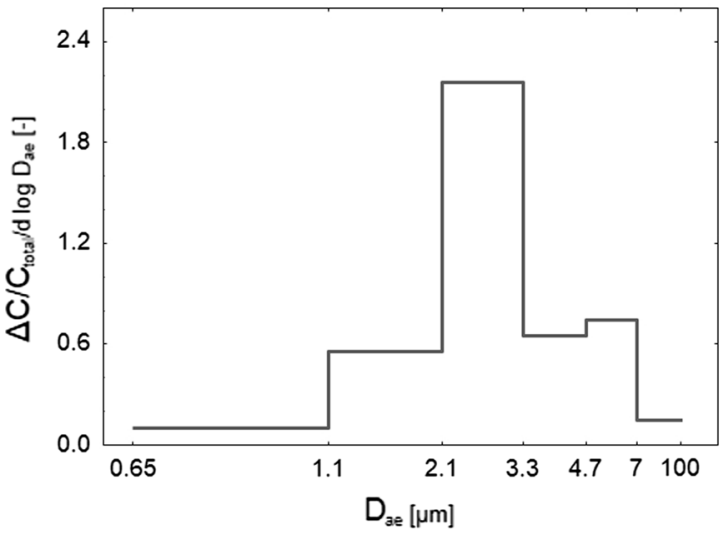

(b) aeration tanks

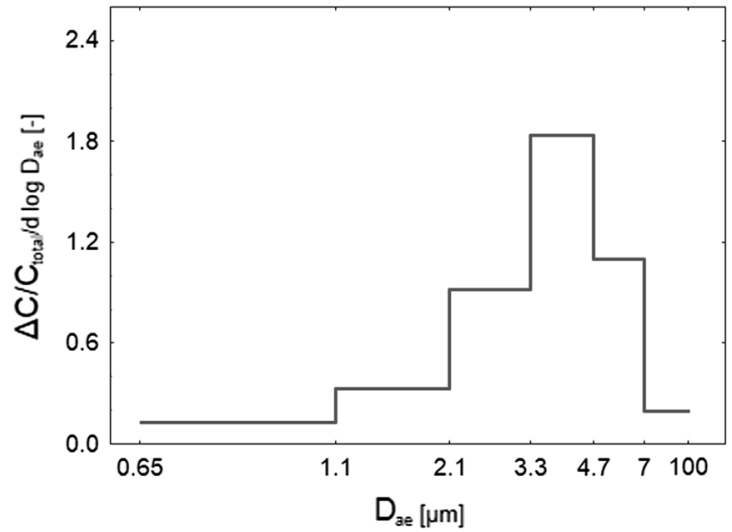

(d) sludge post-processing

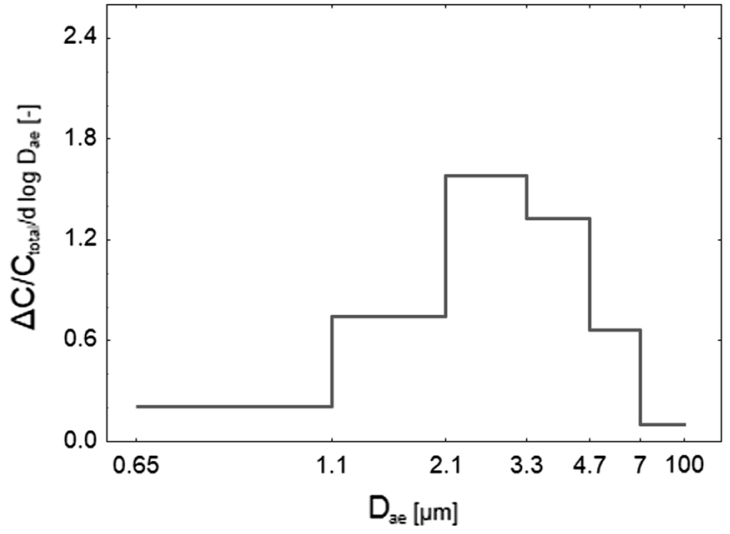

Fig. 3 Size distributions of airborne bacteria collected in the studied wastewater treatment plants

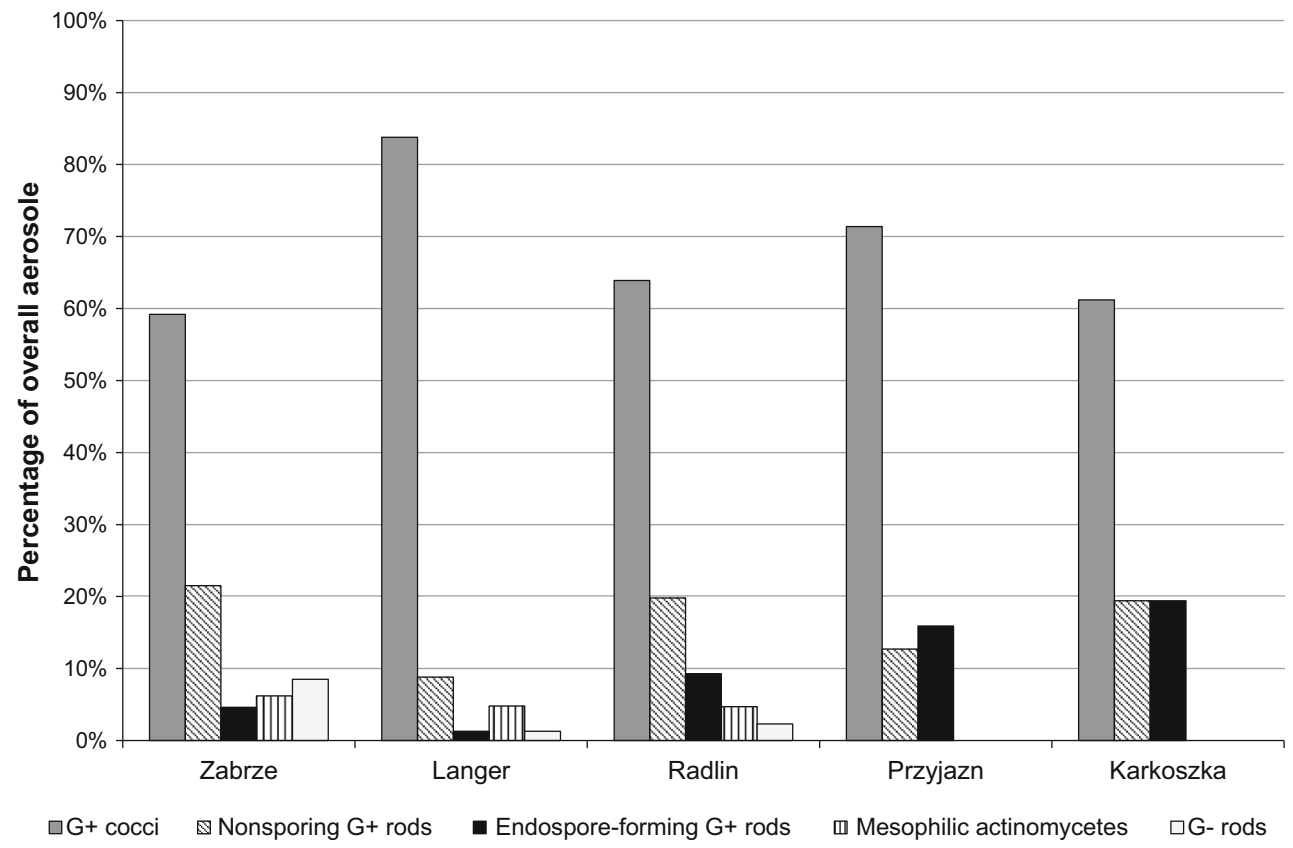

Fig. 4 Viable bacteria genera identified in 5 studied wastewater treatment plants 
Detailed analysis of the isolated bacteria indicates occurrence of 21 species, belonging to 11 from the genera. The most frequently occurring were bacteria types Staphylococcus (6 species) and Bacillus (3 species). Among them, the following bacterial species could be identified:

Gram-positive cocci: Staphylococcus gallinarum, Staphylococcus lentus, Staphylococcus xylosus, Kocuria rosea, Staphylococcus sciuri, Staphylococcus auricularis, Micrococcus luteus, Micrococcus spp., Kocuria varians, Staphylococcus cohnii; Nonsporing Gram-positive rods: Brevibacterium spp., Microbacterium spp., Rothia mucilaginosa, Corynebacterium spp.; Endospore-forming Gram-positive bacilli: Bacillus firmus, Bacillus mycoides, Bacillus cereus; Mesophilic actinomycetes: Streptomyces spp., Nocardia spp.; Gram-negative rods: Pseudomonas spp., Pseudomonas stutzeri.

It should be mentioned that in the wastewater treatment plants "Myszków," in 2002 the Gram-negative bacteria contributed about $35 \%$ to the total bacterial aerosol, while in this study, their contribution did not exceed $8.5 \%$ what can indicate that the hygienic and technological advancement has been improved in Polish WWTPs during the last decade (Wlazło et al. 2002). The reduction in Gram-negative bacteria emission should still remain as one of the purposes to improve the environmental quality in WWTPs. Other studies, reviewing the main health effects among the workers revealed that even though the case of the symptoms is unknown, the results suggested that endotoxin in Gram-negative bacteria may be one of the possible causes (Thorn and Kerekes 2001).
Obtained results concerning identification of fungi species from the wastewater treatment plant's bioaerosol, collected in aeration tanks section, are presented in Fig. 5. Results obtained for all treatment plants show that the most frequently occurring airborne fungi were Cladosporioides species (C. herbarum and C. cladosporides). C. herbarum dominated in sampled fractions $>3.3 \mu \mathrm{m}$, while $C$. cladosporides appears more often in finer fractions. In the sample "Z" also significant contribution of Candida sp. was found. In the all studied wastewater treatment plants, Rhodotorula sp. was also found in the fungal aerosol. Other identified species were: Mycelia sterilia complex, and occasionally Penicillium sp. The high frequency of the occurrence of the Fusarium graminearum should be also noted.

Results of antibiotic resistance testing (Table 5) can be presented as the inhibition rate of growth diameter around antimicrobial susceptibility testing disks, mean values in case of each antibiotic and tested strain (in millimeters).

It can be seen that among the isolated species, the highest antibiotic resistance revealed Bacillus species (especially B. mycoides), what is evidenced by obtaining low growth inhibition area. On the other hand, the most antibiotic-sensitive group of bacteria (from the isolated cultures) is Kocuria sp., except the influence of quinolones, sulfonamides and nitrofurantoin. Among the tested groups of the antibiotics, the least antimicrobial activity toward airborne bacteria isolated from the WWTPs is quinolones and sulfonamides. Only few species were sensitive to them. The most effective antibiotics were penicillins,

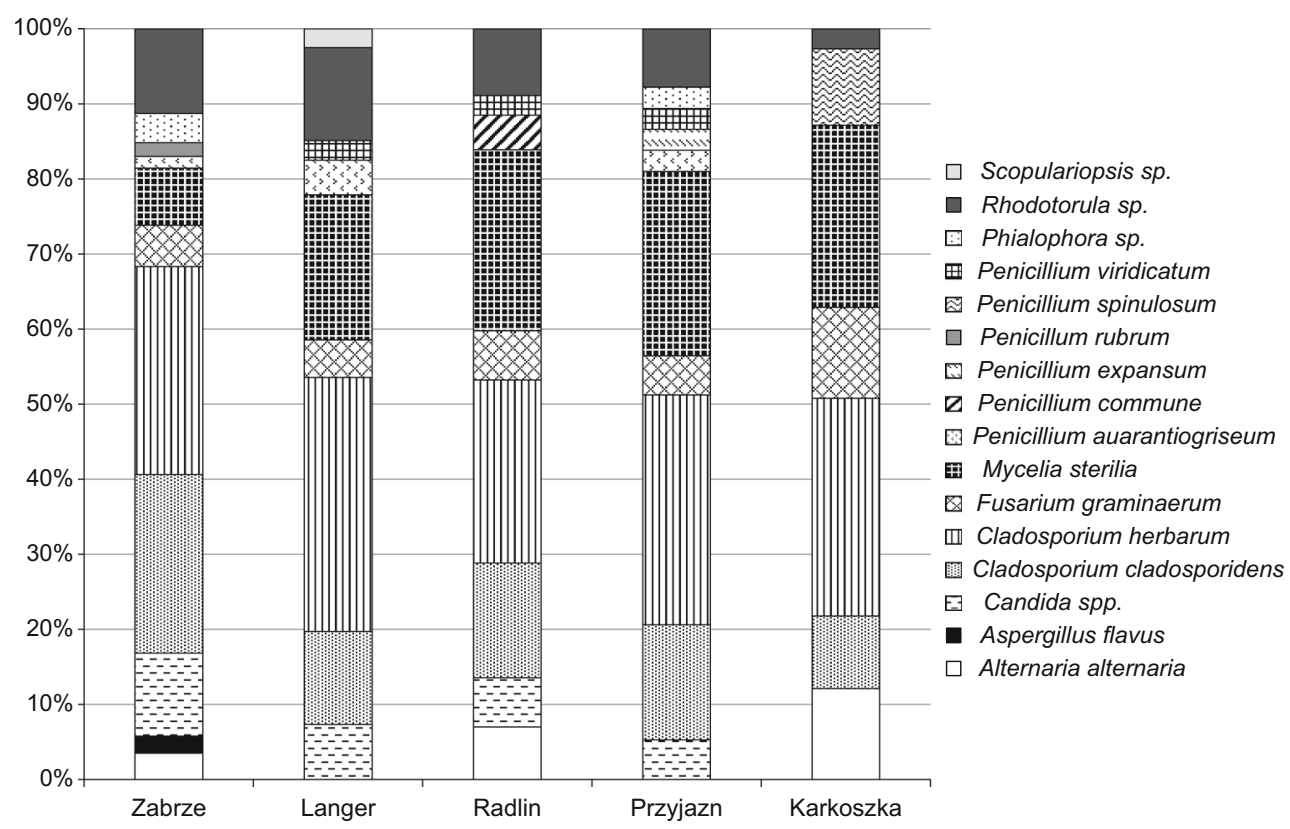

Fig. 5 Airborne fungi species identified in samples collected in the following wastewater treatment plants 


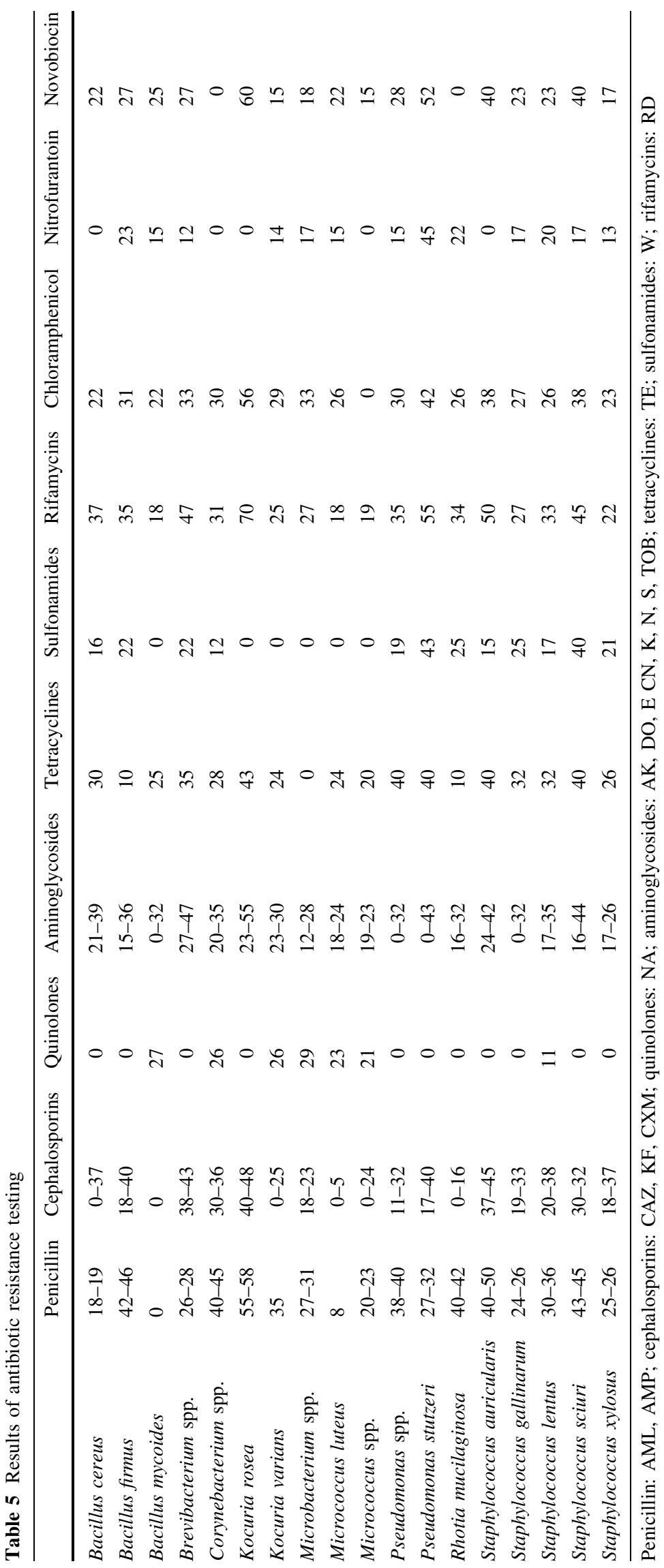


cephalosporins and aminoglycosides, which are commonly used in the antibiotic treatment.

Currently there are almost no published studies concerning the antibiotic resistance of the bioaerosols emitted in wastewater treatment plants. Research concerning the antimicrobial resistance of airborne bacteria collected in Gwalior trade fair (urban area, central India) indicated that during the fair the antibacterial resistance of the suspected strains (S. aureus, Staphylococci, Enterococcus sp., Bacillus sp., Escherichia coli and Pseunomonas sp.) increased (Yadav et al. 2013). Other studies conducted in China concerning identification of antibiotics and antimicrobial strains in soil from wastewater irrigation areas. Authors showed that even in locations, where the antibiotics were not detected, resistant strains were still observed (Chen and Zhang 2013).

The wide application of antibiotics in human and veterinary medicine has led to large-scale dissemination of bacteria resistant to antibiotics in different elements of the environment. The main sources of resistant bacteria are manure and liquid manure of animals as well as human excretions. They serve as a reservoir for bacteria with multiple resistances. Endogenous bacterial biota plays an important role as acceptor and donor of transmissible drug resistance genes. However, further investigations are required concerning effect of antibiotic resistance strains released from WWTPs on the surface waters, soil and air. Future evaluation and control are needed to evaluate and reduce public health risk.

Previous studies on antibiotic-resistant bacterial population in wastewater treatment plants have been done only in aquatic environments. Few of them have focused on the antibiotic-resistant bacteria, among them on E. coli and Acinetabacter spp. in the effluents of WWTPs and their receiving water body (Chen and Zhang, 2013; Schwartz et al. 2003; Reinthaler et al. 2003; Zhang et al. 2009; Gao et al. 2012). Reinthaler et al. (2003) evaluated resistance patterns of $E$. coli in wastewater treatment plants (WWTPs). Investigations have been done in sewage, sludge and receiving waters from the WWTPs. The highest resistance rates were found in the following: penicillin (ampicillin and piperacillin), cephalosporin group (cefalotin and cefuroxime), quinolone (nalidixic acid) and trimethoprime/sulfamethoxazole, and for tetracycline. Of all the investigated antimicrobial substances, the highest rate of resistance was noted for tetracycline (up to 57\%). Korzeniewska et al. (2013) investigated the contamination degree of hospital effluents and municipal sewage (inflow, sewage in aeration tank, outflow) with antibiotic-resistant and beta-lactamases producing E. coli strains. E. coli strains emission to the air near selected WWTP facilities and to the river, where the treated effluent is discharged, was also determined. The results obtained by the authors indicated that antibiotic-resistant $E$. coli strains were emitted from sewage to the atmospheric air near WWTPs and their surroundings or directly into the water sources. Płaza et al. (2013) evaluated the antibiotic resistance of strains isolated from WWTP effluent. 90\% of isolated E. coli was categorized as resistant. The highest resistance frequencies were found for the following: cefalotin and erythromycin $(90 \%)$, nitrofurantoin $(94 \%)$, rifampicin $(97 \%)$ and novobiocin $(100 \%)$.

In the present study, the collection of bacterial strains was also analyzed for multiple antibiotic resistance (MAR). The data indicated that $88 \%$ of bacteria showed resistance to $8-15$ antibiotics and $3 \%$ of isolates were resistance to 19 tested antibiotics. No strain was detected to be resistance from 0 to 5 antibiotics. The decrease in susceptibility of bacterial isolates to antibiotics was probably caused by the presence of these compounds in the wastewaters and the long exposition of $E$. coli strains to them. Zhang et al. (2009) detected that resistance among Acinetobacter isolates to 3 antibiotics (amoxicillin, chloramphenicol and rifampin) and multi-drug resistance (more than 3 antibiotics) significantly increased from the raw influent samples to the final effluent samples.

\section{Conclusion}

Characteristics of bioaerosol collected in different wastewater treatment plants in Poland suggest that the levels of airborne fungi were very similar to those registered at the background location. In case of bacterial aerosol, the existing differences in the concentration levels between the sampling sites made it possible to identify the main its sources. The highest amount concentration of bacterial aerosol was found in these parts of wastewater treatment plant, where activated sludge post-processing and (in some plants) the process of mechanical purifying are conducted. The size distributions of airborne bacteria obtained near the clarifiers, and the sludge post-processing had the peak in the fine particles while in the section of mechanical treatment, as well as in the aeration tanks the peak appeared in the size range more coarse fraction. The patterns of the size distributions shown that collected bioaerosols consist mainly of respirable particles, which can penetrate into lower respiratory tracts and cause possible threat.

The most occurring species in the sampled bacterial aerosol were Gram-positive cocci and nonsporing Grampositive rods. Other bacteria groups, involving endosporeforming Gram-positive bacilli, mesophilic actinomycetes, and Gram-negative rods, contributed around $25 \%$ of the total bacterial aerosol in the studied plants. The most 
occurring airborne fungi were Cladosporidies species $(C$. herbarum and $C$. cladosporides). In all the studied wastewater treatment plants, Rhodotorula sp. was also frequently found. Other identified species were: Mycelia sterilia complex, Fusarium graminearum and occasionally Penicillium sp.

Among the isolated airborne bacteria, the most antibiotic-resistant features are present in the Bacillus species (especially B. mycoides).

The fact that collected bioaerosols were mostly consisting of mesophilic, partially antibiotic-resistant and respirable microorganisms might have negative impact on human health, causing infections.

Acknowledgements This publication was done under Grant BKM/ 510/RIE-2/2015 (08/020/BKM15/0009), funded by Ministry of Science and Higher Education, Poland. The first author was supported by the DoktoRIS-Scholarship Program for Innovative Silesia, cofinanced by the European Union under the European Social Fund. We acknowledge Ewa Bragoszewska, PhD, Silesian University of Technology, for her help in the laboratory work.

Open Access This article is distributed under the terms of the Creative Commons Attribution 4.0 International License (http:// creativecommons.org/licenses/by/4.0/), which permits unrestricted use, distribution, and reproduction in any medium, provided you give appropriate credit to the original author(s) and the source, provide a link to the Creative Commons license, and indicate if changes were made.

\section{References}

ACGIH (1989) Guidelines for the assessment of bioaerosols in indoor environment. In: American conference of governmental industrial hygienists, Cincinnati, Ohio

Bauer H, Fuerhacker M, Zibuschka F, Schmid H, Puxbaum H (2002) Bacteria and fungi in aerosols generated by two different types of wastewater treatment plants. Water Res 36:3965-3970. doi:10.1016/S0043-1354(02)00121-5

Bouki C, Venieri D, Dimadopoulos E (2013) Detection and fate of antibiotic resistant bacteria in wastewater treatment plants: a review. Ecotoxicol Environ Saf 91:1-9. doi:10.1016/j.ecoenv. 2013.01.016

Chen H, Zhang M (2013) Occurrence and removal of resistance genes in municipal wastewater and rural domestic sewage treatment systems in eastern China. Environ Int 55:9-14. doi:10.1016/j. envint.2013.01.019

Di Giulio M, Grande R, Di Campli E, Di Bartolomeo S, Cellini L (2010) Indoor air quality in university environments. Environ Monit Assess 170:509-517. doi:10.1007/s10661-009-1252-7

Fracchia L, Pietronave S, Rinaldi M, Martinotti MG (2006) Siterelated airborne biological hazard and seasonal variations in two wastewater treatment plants. Water Res 40:1985-1994. doi:10. 1016/j.watres.2006.03.016

Gao P, Munir M, Xagoraraki I (2012) Correlation of tetracycline and sulfonamide antibiotics with corresponding resistance genes and resistant bacteria in a conventional municipal wastewater treatment plant. Sci Total Environ 421-422:173-183. doi:10. 1016/j.scitotenv.2012.01.061
Haas D, Unteregger M, Habib J, Galler H, Marth E, Reinthaler FF (2009) Exposure to bioaerosol from sewage systems. Water Air Soil Pollut 207:49-56. doi:10.1007/s11270-009-0118-5

Karra S, Katsivela E (2007) Microorganisms in bioaerosol emissions from wastewater treatment plants during summer at a Mediterranean site. Water Res 41:1355-1365. doi:10.1016/j.watres. 2006.12.014

Korzeniewska E, Filipkowska Z, Gotkowska-Płachta A, Janczukowicz W, Dixon B, Czułowska M (2009) Determination of emitted airborne microorganisms from a BIO-PAK wastewater treatment plant. Water Res 43:2841-2851. doi:10.1016/j.watres.2009.03.050

Korzeniewska E, Korzeniewska A, Harnisz M (2013) Antibiotic resistant Escherichia coli in hospital and municipal sewage and their emission to the environment. Ecotoxicol Environ Saf 91:96-102. doi:10.1016/j.ecoenv.2013.01.014

Laitinen S, Kangas J, Kotimaa M, Liesivuori J, Martikainen PJ, Nevalainen A, Sarantila R, Husman K (1994) Workers' exposure to airborne bacteria and endotoxins at industrial wastewater treatment plants. Am Ind Hyg Assoc J 55:1055-1060. doi:10. 1080/15428119491018330

Li J, Zhou L, Zhang X, Xu C, Dong L, Yao M (2016) Bioaerosol emissions and detection of airborne antibiotic resistance genes from a wastewater treatment plant. Atmos Environ 124:404-412. doi:10.1016/j.atmosenv.2015.06.030

Michael I, Rizzo L, McArdell CS, Manaia CM, Merlin C, Schwartz T, Dagot C, Fatta-Kassinos D (2013) Urban wastewater treatment plants as hotspots for the release of antibiotics in the environment: a review. Water Res 47:957-995. doi:10.1016/j.watres. 2012.11.027

Nevalainen A, Pastuszka J, Liebhaber F, Willeke K (1992) Performance of bioaerosol samplers: collection characteristics and sampler design considerations. Atmos Environ 26A:531-540. doi:10.1016/0960-1686(92)90166-I

Novo A, André S, Viana P, Nunes OC, Manaia CM (2013) Antibiotic resistance, antimicrobial residues and bacterial community in urban wastewater. Water Res 47:1875-1887. doi:10.1016/j. watres.2013.01.010

Pascual L, Pérez-Luz S, Adela-Yáñez M, Santamaría A, Gibert K, Salgot M, Apraiz D, Catalán V (2003) Bioaerosol emission from wastewater treatment plants. Aerobiologia 19:261-270. doi:10. 1023/B:AERO.0000006598.45757.7f

Pastuszka JS, Paw UKT, Lis DO, Wlazło A, Ulfig K (2000) Bacterial and fungal aerosol in indoor environment in Upper Silesia Poland. Atmos Environ 34:3833-3842. doi:10.1016/S13522310(99)00527-0

Pastuszka JS, Marchwińska-Wyrwał E, Wlazło A (2005) Bacterial aerosol in the Silesian hospitals: preliminary results. Pol J Environ Stud 14:883-890

Płaza G, Turek A, Szczygłowska R (2013) Characterization of E. coli strains obtained from waste water effluent. Int J Environ Res 2:67-74

Reinthaler FF, Posch J, Feierl G, Wüst G, Haas D, Ruckenbauer G, Masher F, Marth E (2003) Antibiotic resistance of E. coli in sewage and sludge. Water Res 37:1685-1690. doi:10.1016/ S0043-1354(02)00569-9

Sánchez-Monedero MA, Aguilar MI, Fenoll R, Roig A (2008) Effect of the aeration system on the levels of airborne microorganisms generated at wastewater treatment plants. Water Res 42:3739-3744. doi:10.1016/j.watres.2008.06.028

Schwartz T, Kohnen W, Jansen B, Obst U (2003) Detection of antibiotic-resistant bacteria and their resistance genes in wastewater, surface water, and drinking water biofilms. FEMS Microbiol Ecol 43:325-335. doi:10.1111/j.1574-6941.2003.tb01073.x

Szyłak-Szydłowski M, Kulig A, Miaśkiewicz-Pęska E (2016) Seasonal changes in the concentrations of airborne bacteria 
emitted from a large wastewater treatment plant. Int Biodeterior Biodegrad 115:11-16. doi:10.1016/j.ibiod.2016.07.008

Thorn J, Kerekes E (2001) Health effects among employees in sewage treatment plants: a literature survey. Am J Ind Med 40:170-179. doi:10.1002/ajim.1085.abs

Wlazło A, Pastuszka JS, Łudzeń-Izbińska B (2002) Assessment of workers' exposure to airborne bacteria at small wastewater treatment plant [Ocena narażenia na aerozol bakteryjny pracowników niedużej oczyszczalni ścieków]. Med Pr 53:109-114 (in Polish)
Yadav J, Kumar A, Mahor P, Goel AK, Chaudhary HS, Yadav PK, Yadav H, Kumar P (2013) Distribution of airborne microbes and antibiotic susceptibility pattern of bacteria during Gwalior trade fair Central India. J Formos Med Assoc. doi:10.1016/j.jfma. 2013.04.006

Zhang Y, Marrs CF, Simon C, Xi C (2009) Wastewater treatment contributes to selective increase of antibiotic resistance among Acinetobacter spp. Sci Total Environ 407:3702-3706. doi:10. 1016/j.scitotenv.2009.02.01 